\title{
English Pronunciation Teaching: Four Case Studies from Finland
}

\author{
Elina Tergujeff \\ University of Jyväskylä, Finland \\ Email: elina.tergujeff@jyu.fi
}

\begin{abstract}
The present study looks at how English pronunciation teaching practices are like in Finnish schools from the primary to upper secondary level; in particular, which methods are used and which items are emphasised. The study was carried out as focussed observations (Hopkins 2008, p. 89), as classroom observations were considered the best way to achieve the aim of this study. Four EFL teachers were each observed for 6-9 lessons within a period of one week. A pre-prepared observation form was used as a tool, and then developed into a categorisation of the teaching methods used by the observed teachers. As for the results, the teachers offered pronunciation teaching very different from each other, but in general the pronunciation teaching was found to be pragmatic and teacher-led, and traditional teaching methods were used. At the segmental level, a strong emphasis was placed on phonemes that have typically been found to be difficult for L1 Finnish-speaking learners (sibilants and affricates). Despite the emphasis on suprasegmentals in pronunciation teaching literature, explicit teaching of suprasegmental features of speech was neglected by the observed teachers.
\end{abstract}

Index Terms-pronunciation teaching, EFL, classroom observations

\section{INTRODUCTION}

Since the late 1980s, when interest in pronunciation teaching as a research topic was on the rise, the focus of pronunciation teaching has shifted from practising individual sounds to concentrating equally on suprasegmental features (e.g. intonation, rhythm, stress) - at least in (English) pronunciation teaching literature (e.g. Seidlhofer 2001; Celce-Murcia et al. 2010, p. 11; Lane 2010, p. 8). Is this the case in the classrooms as well? This paper addresses the issue in the context of Finland, where English and many other foreign languages are studied extensively and language skills are highly valued. In general, a great deal is invested in language studies in Finnish schools, and according to 2009 statistics $40.1 \%$ of the year's upper secondary school graduates had studied three different languages in addition to their mother tongue, and $11.0 \%$ had studied four. English is the most widely studied foreign language in Finland. Nearly all children study it as their first foreign language: $99.6 \%$ of all upper secondary school graduates in 2009 had begun their English studies in the lower classes of basic education ${ }^{1}$. (Kumpulainen 2010, pp. 88-89.) Besides education, English has a grown status in Finnish working life and people's leisure activities (see Leppänen et al. 2011).

The pronunciation skills of advanced Finnish learners of English (university students of English) have been recently studied by Lintunen (2004). Lintunen's study, which was restricted to segmentals, reveals that even advanced Finnish learners of English make systematic errors (or, deviations from the standard) in their pronunciation. This result led Lintunen (2004, p. 215) to suggest that pronunciation is not given enough attention in school teaching. However, this critique aimed at teachers is only based on the learners' pronunciation skills, not on any empirical work on EFL teaching, teacher surveys or the like. Thus, Lintunen's study raises questions regarding how English pronunciation teaching is carried out in Finnish schools if the learning results are found fault with. This paper, part of my ongoing $\mathrm{Ph} . \mathrm{D}$. project, aims to shed light on this question and to fill the research gap in English pronunciation teaching in Finland. A special interest is taken in both teaching methods and the contents of teaching. The following research questions were set for the present study:

(1) Which methods are used in teaching English pronunciation in the context of Finnish schools?

(2) Which aspects are emphasised in English pronunciation teaching in the context of Finnish schools?

To answer these questions, classroom observations in Finnish schools were arranged and the study described in Chapter III was conducted.

\section{THEORETICAL BACKGROUND}

English pronunciation teaching has undergone a change in focus from what is called a narrow approach concentrating on segmentals - to a broader one that emphasises suprasegmentals and regards pronunciation as an integral part of oral language use (e.g. Morley 1991). This expanded concept of pronunciation operates top-down, and

\footnotetext{
${ }^{1}$ The compulsory basic education for 7- to16-year-olds in Finland lasts nine years. For more information about the Finnish educational system, see e.g. Kumpulainen (2010, p. 222).
} 
includes more focus on longer stretches of speech, the effects of voice-setting, stress and intonation, as well as coarticulation phenomena such as shortenings, weakening, and assimilation (Pennington \& Richards 1986). Included in the concept is also the simultaneous teaching of accuracy and fluency (Celce-Murcia et al. 2010, p. 361), so the contents of the narrow approach (segmentals) are not abandoned even though a broader approach is adopted. Here we might also use the term balanced approach (e.g. Lane 2010, p. 8), recognising the need for both segmental and suprasegmental training. The teacher's role is regarded more as that of a coach (Morley 1991), and learner-centredness is seen as a key issue: learner autonomy and authority should be recognised, and the learners' personality, ego and identity issues as well as different learner modes should be taken into consideration in pronunciation teaching (Celce-Murcia et al. 2010, p. 362).

According to recommendations in the literature, method-wise the teaching should be grounded in meaningful practice that considers the learners' needs for real-life situations (Morley 1991), and to communicative language teaching (CLT) (Celce-Murcia et al. 1996, p. 316; Seidlhofer 2001). However, applying the principles of CLT to pronunciation teaching is more easily said than done, and developing communicative pronunciation teaching methods has been urged for long (Seidlhofer 2001; Celce-Murcia et al. 2010, p. 9). Computer-assisted instructional technology could naturally be made use of in pronunciation teaching, and it has also been suggested that the teaching could benefit from the ideas and techniques of other disciplines such as drama (Celce-Murcia et al. 2010, p. 362). On a personal note, it pleases me greatly that there is a call for more emphasis on the link between speaking and listening, which can even be seen as two sides of the same coin, namely, spoken language (Cauldwell 2003). Related to this link, a very welcome point is suggested by Jenkins (2000, pp. 208-212) in connection with the concept of English as an International Language(EIL). She suggests that instead of getting rid of one's foreign accent, learners would benefit from so-called accent addition, i.e. adding different (especially non-native) accents of English to their perceptive repertoire (but not necessarily to their productive repertoire). Overall Jenkins (2000) and many scholars involved in the study of English as a lingua franca (ELF) (for more about ELF research, see e.g. Mauranen \& Ranta 2009; Seidlhofer 2011) speak for intelligibility (as opposed to perfection) as the main aim of pronunciation teaching.

Contrastive Finnish-English studies have been extensively conducted, and the pronunciation problem areas of L1 Finnish-speakers of English are well mapped, particularly regarding the segmental level (Wiik 1965, 1966; Lehtonen, Sajavaara \& May 1977; Suomi 1980; Morris-Wilson 1992; about suprasegmentals see e.g. Hirvonen 1967, 1970; Niemi 1984; Toivanen 2001). The L1 Finnish-speaking learners of English are prone to encounter problems in the following areas due to differences in the sound systems of Finnish and English. First, plosives give trouble to Finns due to voicing distinctions, as do sibilants and affricates, most of which do not occur in Finnish. Plosives are also problematic in the sense that aspiration is not a familiar phenomenon in the L1 of Finns. Similarly, interdentals do not occur in the Finnish language. The v-w distinction causes problems for Finnish learners of English, whereas vowel sounds do not usually bring about noticeable difficulties. When Lintunen (2004) made a segmental analysis of Finnish university students' English pronunciation, he found that most difficulties lie in the above-mentioned areas, and the students made significantly fewer errors in vowel sounds than in consonants.

Unfortunately, researchers have not taken an interest in pronunciation teaching in Finnish schools. What is known about the matter is mainly based on learners' opinions, and covers only few phonetic teaching methods. Lintunen (2004) asked university students $(\mathrm{n}=108)$ whether they had been taught how to read phonetic symbols during their school years, and the participants' answers do not indicate a strong phonetic orientation in school teaching: only 5.6\% of the participants said that they had been taught how to read all of the relevant symbols, whereas $50.0 \%$ were of the opinion that none had been taught to them. A similar study by Tergujeff, Ullakonoja and Dufva (2011), also conducted with university students $(\mathrm{n}=207)$, revealed similar results: In the teaching of English, phonetic script was taught often to only $1 \%$ and never to $25 \%$ of the respondents; phonetic listening tasks, e.g. sound discrimination, were done often in the teaching received by $1 \%$ and never in the teaching received by $47 \%$ of the respondents; and finally, none of the respondents indicated they had often received training in intonation and speech rhythm, whereas $48 \%$ indicated that they had never received teaching in these areas.

As pointed out by previous studies, learners' opinions suggest that phonetic training is not frequently used in English pronunciation teaching in Finnish schools, even though phonemic transcription can be seen as a useful tool in pronunciation teaching for L1 Finnish-speaking learners in particular. This is due to the fact that the learners are used to a close letter-to-sound correspondence in their L1 (Suomi, Toivanen \& Ylitalo 2008, p. 141), and a correlation between pronunciation skills and skills in phonemic transcription has been suggested (Lintunen 2004).

\section{METHOD}

This section presents the method of the study. In order to obtain first-hand information about English pronunciation teaching, classroom observations were chosen as the method. In the description of the classroom observations, the discussion is partly devoted to explaining why the record-taking method of the observations was chosen. Finally, the cases and data analysis are introduced.

\section{A. Classroom Observations}


Teachers from four different schools were chosen for this study. I attended EFL lessons by one teacher from each school without participating in the teaching in any way. Each teacher was observed for 6-9 lessons within a period of one week. Two of the schools were small village schools with teaching groups of 4 to 15 pupils, and the two others were medium-sized schools with teaching groups of 14 to 28 pupils. The teachers knew that the classes were observed for research purposes, but the focus of the observations was revealed to them only after the period of observation, in order not to influence their teaching and behaviour in class. They did not know whether the focus of the observation was on them or their pupils.

The choice of the record-keeping method of the observations was made between written accounts and video recordings. Audio recording was not seen as an option due to practical reasons - classrooms are too large and often have poor acoustics, teachers move about, and important information can be drowned in other voices and general noise. The combination of recording and writing transcripts was ruled out because the study did not aim at a detailed analysis of what is said during the lessons (cf. Wragg 1999, p. 14). Video recording would have offered a good, re-playable visual and audio account when analysing the data, but teachers and pupils, if not used to being video recorded, might have been affected by the presence of the video camera, and getting appropriate permissions for the video recordings from the schools, the teachers and the pupils or their parents if they were under-aged could have been problematic. Overall, it might have been more difficult to find teachers willing to participate. Written notes were considered adequate for the present purposes and were chosen as the method, though immediate decisions about what to record were required and the possibility of action replay was excluded. However, an observer with pen and paper rather than a video camera was estimated to have less of an effect on the teachers and the pupils (cf. ibid., pp. 16-17)

Data gathering was carried out as focussed observations (Hopkins 2008, p. 89). An observation form was prepared beforehand and filled in during the lessons. The form consisted of a list of pronunciation teaching methods drawn from pronunciation teaching literature (Seidlhofer 2001; Celce-Murcia et al. 1996) and a textbook analysis of current EFL textbooks used in Finland (Tergujeff 2010). In addition, the form included space for notes after each pronunciation teaching method in the list, which was used to describe the procedure in class if the method in question was used by the teacher.

After the observation period the teachers were asked to fill in a short questionnaire regarding their education, work experience, and teaching materials they use in their pronunciation teaching. Because of the relatively short observation period, the teachers were also asked to estimate how much they taught pronunciation during the observations compared to usual.

\section{B. Cases}

The teachers were chosen for this study so that they would represent teaching at all school levels from basic education to upper secondary school. I also wanted to observe teachers from both small and bigger schools in terms of teaching group size, as a larger teaching group is sometimes named as a factor that makes pronunciation teaching difficult. Because temporary and part-time teaching posts are often filled by teachers without full formal qualifications ${ }^{2}$, and in the lower classes (1-6) of basic education primary school teachers (and not EFL subject teachers) are often in charge of teaching English to young learners, such teachers were included in the present study.

The four observed teachers - Ms Laine, Ms Sten, Ms Niemi and Ms Virta (the names have been changed) - had teaching experience varying from 10 to 23 years. Two of the teachers were qualified EFL subject teachers by Finnish standards, holding an M.A. degree. One held a B.A. degree only and one was a professional primary school teacher with ELT specialisation. The professional primary school teacher, Ms Laine, was responsible for teaching English to children in basic education classes 3-6, and the teacher with a B.A. degree, Ms Sten, taught pupils in basic education classes 7-9. Of the formally qualified EFL subject teachers, Ms Niemi taught pupils both in basic education (classes 79) and in upper secondary school, and Ms Virta taught in upper secondary school. Relevant background information about the teachers is given in Table 1 below.

TABLE 1.

BACKGROUND INFORMATION ABOUT THE OBSERVED TEACHERS.

\begin{tabular}{llll}
\hline Teacher & Qualifications & Experience & Pupils \\
\hline Ms Laine & M.Ed. & 23 years & $8-13$ years old \\
\hline Ms Sten & B.A. & 13 years & $13-16$ years old \\
\hline Ms Niemi & M.A. & 10 years & $13-19$ years old \\
\hline Ms Virta & M.A. & 12 years & $16-19$ years old \\
\hline
\end{tabular}

Ms Laine, a professional primary school teacher, was observed for eight 45-minute English lessons during a period of one week in spring 2009. Her education includes some studies of English, but she is not a formally qualified EFL subject teacher by Finnish standards. She teaches English at the beginners' level, i.e. to basic education pupils aged 8 to 13, and has teaching experience of 23 years. The size of her teaching groups was 8 pupils on average. A school helper was at her disposal and attended the classes regularly. When asked about her choice of pronunciation teaching materials

\footnotetext{
${ }^{2}$ In Finland, fully qualified EFL subject teachers hold an M.A. degree in English, including a teacher training programme/pedagogy as a minor subject in the degree.
} 
after the classroom observations, she stated that she uses exercises included in the course books, other materials such as cards and pictures, and materials she prepares herself. She also stated that during the classroom observation period, she taught the same amount of pronunciation compared to the usual.

Ms Sten was observed for nine 45-minute lessons during a period of one week in spring 2009. She holds a B.A. degree in English, but is not a qualified EFL teacher by Finnish standards. She teaches English to pupils aged 13 to 16 at the basic education level. The size of her teaching groups was 17 pupils on average. She has 13 years of teaching experience. After the classroom observations, she said that she uses pronunciation exercises included in the course books and exercises that she prepares herself. She stated that she taught less pronunciation during the observations than in general.

Ms Niemi was observed for nine 45-minute lessons during a period of one week in spring 2009. She is a formally qualified EFL subject teacher, and teaches English at the basic education level and also in upper secondary school, i.e. to pupils aged 13 to 16 and 16 to 19 . Her teaching groups averaged 11 pupils. She has 10 years of teaching experience. When asked after the classroom observations, she indicated that she uses pronunciation exercises included in the course books, materials from other sources and her own materials. She estimated that she taught pronunciation the regular amount during the classroom observation period.

Ms Virta, also a formally qualified EFL subject teacher, was observed for six 75-minute lessons during a period of one week in spring 2009. She teaches English in upper secondary school, i.e. to pupils aged 16 to 19 . The average size of her teaching groups was 25 pupils, and she has teaching experience of 12 years. In pronunciation teaching she uses exercises that are included in the course book and in specific pronunciation and oral skills textbooks. In addition, she prepares materials herself. She taught the regular amount of pronunciation during the period of classroom observations.

\section{Data Analysis}

Analysis of the classroom observations began by excluding material that represented general oral skills teaching instead of specific pronunciation teaching. In drawing the line between these two, the same criterion was used as in the textbook analysis by Tergujeff (2010): specific pronunciation teaching explicitly directs the learner's focus towards pronunciation. Due to this definition, recasts (see Nicholas, Lightbow \& Spada 2001) for example were not counted as pronunciation practice. However, reading aloud tasks were included, as they were not seen to serve any other (e.g. communicative) purpose than pronunciation practice. The same decision was made concerning the use of nursery rhymes, which are regularly mentioned in pronunciation teaching literature and can offer good practice of speech rhythm. The final data was then classified, which was simple because an observation form had been used. The form served as a starting point for the classification. Further, the data was studied in order to analyse the contents of pronunciation teaching, i.e. what was and was not taught, at both the segmental and suprasegmental levels.

\section{FINDINGS}

This chapter presents the findings of the study. In the first section, a summary of all teaching methods used by the observed teachers is presented to give an overall picture of the range of methods. In the following sections, the idea is not to describe each and every pronunciation teaching exercise, but to demonstrate the teaching during the classroom observations and to highlight issues of interest from the viewpoint of my research questions. In more detail I shall describe the teacher corrections and the teachers pointing out pronunciation, phonetic training and ear training. Listen and repeat exercises were mainly imitating word lists the teacher read from the course books. Similarly, reading aloud was often done from course books. These methods are not dealt with any further. An example of a pronunciation rule is provided within one of the sections. Finally, I shall explore which teaching methods were not used and which areas of pronunciation were not taught by the observed teachers.

\section{A. Teaching Methods}

During the observed 32 EFL lessons, 111 pronunciation teaching activities were detected. These are presented in a teacher-specific manner in Table 2 below. Overall the activities were very traditional, including the time-honoured listen and repeat tasks, reading aloud, giving rules and teachers correcting and pointing out how to pronounce. Some phonetic training and ear training were also found to be used by the observed teachers. In addition, some rhymes were used in pronunciation teaching, and tactile reinforcement (reinforcement through the sense of touch) on one occasion. 
TABLE 2.

SUMMARY OF TEACHING METHODS.

\begin{tabular}{llllll}
\hline \multirow{2}{*}{ Teaching method } & \multicolumn{5}{l}{ Times used in teaching } \\
\cline { 2 - 6 } & Ms Laine & Ms Sten & Ms Niemi & Ms Virta & Total \\
\hline Listen and repeat & 34 & - & 2 & 3 & 39 \\
\hline Teacher corrects & 11 & 4 & 8 & - & 23 \\
\hline Teacher points out & 5 & - & - & 16 & 21 \\
\hline Read aloud & 4 & - & 6 & - & 10 \\
\hline Phonemic script & $2 *$ & - & - & 7 & 9 \\
\hline Rhyme & 3 & - & - & - & 3 \\
\hline Rules & 1 & - & - & 1 & 2 \\
\hline Dictation/spelling & 1 & - & 1 & - & 2 \\
\hline Discrimination & 1 & - & - & - & 1 \\
\hline Tactile reinforcement & - & - & - & 1 & 1 \\
\hline Total & 62 & 4 & 17 & 28 & 111 \\
\hline & $*$ mentioned, not actively used & &
\end{tabular}

As predicted, the teachers showed great variation in their teaching methods. Ms Laine, teaching beginners, was by far the most active in teaching pronunciation: she used pronunciation tasks in most of the categories that were found to be in use by the four teachers. More than half of all pronunciation tasks detected during the observations were found in Ms Laine's teaching. Ms Sten, teaching at intermediate level, was the complete opposite of Ms Laine. She did not teach much pronunciation during the observed lessons, and when she did, she always used the same method: correcting the pupils. Ms Niemi and Ms Virta were slightly more active in pronunciation teaching, but they used different methods sparingly. They each used different methods from four or five categories.

A closer look at especially Ms Virta's choice of methods demonstrates that the proficiency level and/or age of the pupils possibly affect teaching. Compared to the other teachers, Ms Virta's pronunciation teaching is more analytical: she concentrates on pointing out pronunciation issues and uses phonetic training frequently. The other teachers are more practical. In their pronunciation teaching, they focus on listen and repeat activities, correcting their pupils and reading aloud tasks. Only Ms Laine used rhyme in her teaching - perhaps nursery rhymes and poems are seen as too childish for teenagers.

\section{B. Teachers Correcting and Pointing Out Pronunciation}

How to teach pronunciation communicatively is a challenge (e.g. Seidlhofer 2001), and this seems to be true for Finnish EFL teachers as well. In the era of communicative language teaching (CLT), it is surprising how teacher-led pronunciation teaching seems to be in the light of these four cases. This is demonstrated for example by the high frequency of teachers correcting pupils' pronunciation. Correcting pupils, however, should not cause negative feelings in pupils, and they should not feel as if they were punished, as stated by Morley (1991). Morley adds it is always the pupil who corrects (or better, modifies) the pronunciation, whereas the teacher's task is to give cues on how to do that. Lane (2010) is also of the opinion that the pupils should be offered an opportunity to self-correct, and suggest an instant cue (e.g. teacher saying "Pronunciation!") to notify the pupil of the mispronunciation without correcting him/her. In fact, this was usually not what the Finnish EFL teachers did. Mainly the teachers corrected their pupils by repeating a mispronounced word in the desired form. On one occasion Ms Sten also repeated the undesired form uttered first by a pupil, and then she explained that the undesired form could be misinterpreted as another word. Ms Niemi came closest to giving cues on how to correct mispronunciations, but in fact gave orders.

Example 1. Ms Niemi to a pupil pronouncing the word honest as [ho nı st]:

"Älä sano h:ta siihen!" (Don't pronounce the h there!)

Example 2. Ms Niemi to a pupil pronouncing the word whole as [whəo l]:

"Sano pelkkänä h:na se alku!" (Pronounce the beginning as a plain h!)

The teachers' corrections and the occasions on which they take up pronunciation issues are of interest in the sense that they reveal possible focus areas of the pupils' pronunciation problems. Another possibility is that they reveal what the teachers regard as important factors in pronunciation. The two possibilities can of course be - and are hoped to be interrelated. The teachers' corrections are summarised in Table 3 below. Most frequently the teachers corrected words that contain sibilants and affricates, e.g. China, ocean, chocolate, Tracy, assistant, penguins (Ms Laine), ${ }^{3}$ dictionary (Ms Sten), future, actually (Ms Niemi). It is predictable that English sibilants cause difficulties for L1 Finnish-speaking learners, as the Finnish phoneme inventory only includes one sibilant, /s/, and no affricates. Therefore, the English sibilant and affricate sounds $/ \mathrm{z}, \int, 3, \mathrm{~d}, \mathrm{t} / \mathrm{are}$ foreign to Finnish learners and difficult to produce for many. Learning to produce these sounds is further complicated by the fact that Finnish traditionally lacks voicing distinctions in consonants.

Another tendency was found in the teachers' corrections of pupils' pronunciation, namely correcting spellinginduced mispronunciations. Such cases were the past perfect had read, had drunk (Ms Sten), honest, and whole (Ms

\footnotetext{
${ }^{3}$ Here it was at times difficult to distinguish whether the correction was directed towards the sibilant/affricate or some other segment or feature, especially with Ms Laine's young pupils.
} 
Niemi). In their L1, Finnish learners of English are used to a transparent letter-to-phoneme correspondence (Suomi et al. 2008, p. 141), and are therefore especially prone to making mistakes caused by the irregular spelling conventions of English (for details about the irregular spelling of English see Wells 2008). As pointed out by Seidlhofer (2001), teachers should be aware of the relationships between orthography and phonology. A good example of such awareness was offered by Ms Laine, when she explained to her young pupils that the letter combination $\langle\mathrm{kn}\rangle$ corresponds to sound /n/. Also, Ms Niemi corrected a pupil's mispronunciation of honest from [ho $\mathrm{n}$ I st] to [o nı st] and of whole from [whəo 1] to [həo 1] (see Examples 1 and 2). Other words that Ms Niemi corrected were psychology, euros, bargains and particularly. In addition to the previously mentioned words, Ms Laine corrected the following words: David, the USA, and the phrase Were David and Ann...?

TABLE 3.

WHAT THE TEACHERS CORRECTED.

\begin{tabular}{ll}
\hline Item corrected & Example words \\
\hline Sibilant sounds & ocean, dictionary \\
\hline Affricate sounds & chocolate, actually \\
\hline Spelling-induced mispronunciations & had read, honest \\
\hline
\end{tabular}

At times, two of the teachers pointed out the desired pronunciation of certain items before the pupils had attempted them. A summary of such cases is presented in Table 4 below. In these instances sibilants and affricates were also in focus. Ms Laine pointed out the affricate in chance by repeating the sound as follows:

\section{Example 3. Ms Laine: "Ch-ch-chance!"}

Ms Virta was very active in pointing out the pronunciation of words that include sibilants and affricates. Such words were decompose, organisation, corporations, religious, garage, and positions. To demonstrate the pronunciation of positions, Ms Virta wrote the word on the blackboard in phonemic script, and the word was persistently practised after the teacher (all together aloud), as she was not content with the pupils' performance. Ms Virta pointed out the pronunciation of the words diner and volunteer as well.

In correcting and pointing out pronunciation, there were instances in which the teacher interfered because a mispronunciation caused or might have caused a change in meaning and therefore potential communication breakdown. Ms Laine, for example, advised her pupils to pay attention to the aspirated $/ \mathrm{k} /$ in cold, in order to not be interpreted as having said gold. Also, she warned the pupils not to mix up beard with beer. Ms Sten corrected a pupil's production of cousin, because in the teacher's words it sounded more like cushion (due to the quality of the first vowel), and Ms Virta reminded her pupils as follows:

\section{Example 4. Ms Virta: "It's Thai - thigh is something else."}

Ms Virta also informed her pupils about words with alternative pronunciation (often British English vs. American English conventions), such as schedule, vase, algae and aluminium/aluminum. In addition, she instructed the pupils on how to distinguish crisis from crises in pronunciation.

TABLE 4.

WHAT THE TEACHERS POINTED OUT.

\begin{tabular}{ll}
\hline Item pointed out & Example words \\
\hline Sibilant sounds & organisation, positions \\
\hline Affricate sounds & chance, religious \\
\hline Potential communication breakdown & cold/gold, beard/beer \\
\hline Alternative pronunciations & schedule, vase \\
\hline
\end{tabular}

\section{Phonemic Script}

That Finnish EFL textbooks emphasise phonetic training, and that phonemic script is strongly present in them (Tergujeff 2010) were not reflected in these four case studies. Only one of the teachers used phonemic script and transcription exercises during the observed lessons, and in addition, one teacher referred to phonemic script - Ms Laine, who once urged her pupils to pay attention to the pronunciation instructions in phonemic script in a word list, and at another occasion noted that they would go through the phonetic symbols later. Despite the strong presence of IPA in Finnish EFL textbooks, phonetic training is not a frequently used pronunciation teaching method in Finnish schools; surveys have shown that pupils do not feel they are well taught e.g. how to read IPA symbols (Lintunen 2004, pp. 187188; Tergujeff et al. 2011).

Ms Virta used phonemic script in her teaching in two ways: to demonstrate pronunciation and in deciphering tasks. The pupils were not asked to transcribe anything themselves. When the teacher demonstrated the pronunciation of individual segments with the help of transcription, it dealt with sibilant sounds, namely /z, $3, \int /$. The two first were found to be among the most problematic sounds for Finnish learners of English, and the last one among those that often cause problems (Lintunen 2004, p. 149). The word casual was quite spontaneously picked up by the teacher and written on the blackboard in phonemic script, which in my view demonstrates her good transcription skills. Then she asked the pupils what sound the symbol 3 stands for. In addition, they repeated the word time after time, and felt the voicing of 
/3 / with their fingers on their throats, giving the pupils some tactile reinforcement (Celce-Murcia et al. 2010, pp. 337338).

\section{Ear Training}

Similar to the productive side of pronunciation, the recommended focus of practice has shifted towards units larger than the segment also in ear training. Morley (1991) suggests focussing more on pronunciation-oriented listening activities in English pronunciation teaching. She notes that particularly sound discrimination and identification tasks were traditionally important components of pronunciation teaching, but that a wider range of listening foci is recommended (ibid.). This was not realised in the observed lessons, and the receptive side of pronunciation was overall seldom practised. Ms Laine presented one sound discrimination exercise, asking her pupils whether they heard a 'hissing sound' in the word sofa like they do in the word ship. She also used a spelling task in her teaching, spelling to pupils herself. Ms Niemi assigned the pupils to dictate sentences to one another.

\section{E. What was Missing?}

As Table 2 shows, a range of pronunciation teaching methods was used by the four teachers. However, there are many methods that could have been used but were not, and in fact a whole area of pronunciation was neglected in the teaching: suprasegmental features. Here again, the idea is not to list all possible pronunciation teaching methods that could have been used, but I shall concentrate on a few main areas which would possibly have benefitted the learners according to recommendations in the literature. None of the teachers gave explicit instruction in intonation, word or sentence stress, nor rhythm, even though these areas of pronunciation have been suggested to be more crucial for intelligibility than individual sounds (Lane 2010, p. 2), and in pronunciation teaching literature it has recommended that these areas were emphasised. This broad approach to pronunciation teaching has also been suggested to lead to better learning results than a narrow one that concentrates on segments (see Derwing, Munro \& Wiebe 1998). However, the pupils received implicit intonation practice in imitation tasks with longer stretches of speech, in read aloud tasks and when reading rhymes. Also, Ms Virta reminded her pupils of intonation in connection with an imitation task by saying:

Example 5. Ms Virta: "Imitoikaa ja muistakaa intonaatio ylös ja alas."

\section{(Imitate and remember: intonation up and down.)}

Learners' overall fluency of speech could also benefit from training connected speech (weak forms, assimilation, elision, linking), but this was not included in the teaching either. However, some have deemed it unnecessary to teach pupils to produce these features, but only to recognise them (Rogerson-Revell 2011). Further, the observed lessons lacked learner-centred pronunciation teaching methods. No so-called awareness-raising tasks or self-evaluations were used. Learning strategies were not dealt with either. It is also noteworthy that no technology or other helping tools (mirrors, charts, images, etc.) were present in the teaching (cf. Celce-Murcia et al. 2010, pp. 10, 354-361).

\section{DisCUSSION AND CONCLUSION}

Positive effects of pronunciation instruction have been reported in numerous studies. These studies suggest that instruction at both segmental and suprasegmental levels can result in improved pronunciation skills, and that teaching methods such as discrimination practice (e.g. Neufeld 1977, 1978 quoted in Neufeld \& Schneiderman 1980; Derwing et al. 1998), concrete rules, giving immediate feedback (e.g. Elliott 1995, 1997), and imitation (e.g. Macdonald, Yule \& Powers 1994) have had positive effects on the learning of pronunciation. In a comparison of narrow/segmental and broad/suprasegmental approaches, Derwing et al. (1998) conclude that the suprasegmental approach is more effective in terms of comprehensibility, accentedness and fluency.

The aim of the present study was to shed light on the methods and focus areas of English pronunciation teaching in the context of Finnish schools. Observing 32 EFL lessons revealed a range of ten different types of pronunciation teaching methods, including traditional imitation tasks, teacher corrections, teachers pointing out pronunciation issues, reading aloud, use of phonemic script and rhymes, presenting rules, dictation/spelling, sound discrimination, and tactile reinforcement. The teachers used different methods to varying degrees, ranging from one teacher (Ms Laine) using nine to another teacher (Ms Sten) using only one. Here it is worth noting that Ms Sten stated after the observations that she had taught pronunciation less than she typically does, whereas the other teachers indicated they taught it the regular amount. Measured by overall frequency in the whole data, the traditional listen and repeat exercises - found effective in e.g. Macdonald et al. (1994) - were the most common pronunciation tasks used during the observations. However, this finding is due to the fact that the method seems to have been Ms Laine's personal favourite - other teachers used it only sparingly. Teacher correction (comparable to immediate feedback in Elliott (1995, 1997)) and pointing out pronunciation issues were also common methods measured by the overall frequency of occurrence, whereas using rhyme, dictation/spelling, tactile reinforcement, and the well-tried methods of discrimination practice (e.g. Neufeld 1977, 1978 quoted in Neufeld \& Schneiderman 1980; Derwing et al. 1998) and presenting rules (e.g. Elliott 1995, 1997) were less popular methods. None of the teaching methods were used by all the four teachers; imitation tasks and teacher correction were both used by three teachers. These two methods can be seen as the most popular ones in my data, as they were most common in terms of both frequency of occurrence and number of teachers using them. 
Overall, the pronunciation teaching practices can be characterised as being teacher-led to a great extent. This does not correlate well with the principles of communicative language teaching (CLT), which usually aims at promoting learner autonomy and being learner-centred. In many instances the teacher interfered with and corrected a pupil's pronunciation, or gave them information about the pronunciation of a word. Communicative pronunciation tasks were hardly used in the observed lessons. Even though we are living the era of CLT, in fact, CLT and pronunciation teaching is a complicated combination, as stated by Seidlhofer (2001): CLT directs the learners' attention to communication and away from form, but a certain formal aspect, such as pronunciation, can be difficult to learn unless one pays attention to it. This is also demonstrated in Elliott $(1995,1997)$.

As a whole, the teachers seemed to be well aware of their pupils' potential problem areas in regards to segments. Sibilant and affricate sounds frequently appeared not only in teacher corrections but also in ear training, phonemic script and when teachers pointed out pronunciation issues. Therefore, the teachers must have had knowledge of the generic difficulty of these sounds to L1 Finnish-speaking learners, attained from experience or literature - or perhaps both. This is a very positive result in regards to Lintunen's (2004) study: the problem areas demonstrated again by his study were emphasised in the observed teaching. Pronunciation teaching given by these four teachers can also be characterised as somewhat pragmatic: the teachers seemed eager to correct their pupils' pronunciation, in particular if it raised the possibility of mispronunciation, thereby leading to communication breakdown. This gives the impression that the teachers emphasise intelligibility in their aims of pronunciation teaching. However, also in this the teachers operated at the level of segmentals, even though suprasegmental features of speech have been found to be more crucial for intelligibility than segmentals (e.g. Pennington \& Richards 1986), and emphasis on suprasegmentals in pronunciation teaching has been suggested to be more effective than emphasis on segmentals (Derwing et al. 1998).

This study addressed only a short period of English pronunciation teaching given by four teachers. The aim was not to make any generalisations about English pronunciation in Finland, nor about the teaching of the observed teachers (for a general view of teaching practices, a survey study of EFL teachers from Finland and other European countries is in progress (Henderson et al., forthcoming)). However, the data offered possibilities for a close examination of pronunciation teaching methods and the contents of English pronunciation teaching in the context of Finnish schools, and resulted in the following main findings. First, the teaching methods, the most popular of which were imitation and teacher correction, were found to be teacher-centred. Second, affricates and sibilant sounds stood out as the main contents of the teaching. Third, the recommended emphasis on prosodic features in pronunciation teaching was not realised during the observed lessons. Finally, a pragmatic approach was found in instances in which the teachers corrected their pupils in order to avoid communication breakdown from mispronunciation. Despite the small sample of the present study, some of these findings may be typical for English pronunciation teaching in general.

\section{ACKNOWLEDGEMENT}

I wish to acknowledge the four teachers, their schools and school headmasters for making this study possible. I would also like to thank Professor Hannele Dufva, Professor Päivi Pahta, and the anonymous reviewer for their valuable comments. This work was funded by Langnet, the Finnish graduate school in language studies.

\section{REFERENCES}

[1] Cauldwell, R. (2003). The two-sides rule in teaching listening and pronunciation. Retrieved http://www.developingteachers.com/articles_tchtraining/two_sides1_richard.htm.

[2] Celce-Murcia, M., Brinton, D.M., Goodwin, J.M. \& Griner, B. (2010). Teaching pronunciation: A course book and reference guide. 2nd edition. Cambridge, UK: Cambridge University Press.

[3] Celce-Murcia, M., Brinton, D.M. \& Goodwin, J.M. (1996). Teaching pronunciation. A reference for teachers of English to speakers of other languages. Cambridge, UK: Cambridge University Press.

[4] Derwing, T.M., Munro, M.J. \& Wiebe, G. (1998). Evidence in Favor of a Broad Framework for Pronunciation Instruction. Language Learning 48, 3. 393-410.

[5] Elliott, A.R. (1995). Foreign Language Phonology: Field Independence, Attitude, and Success of Formal Instruction in Spanish Pronunciation. Modern Language Journal 79(4), 530-542.

[6] Elliott, A.R. (1997). On the teaching and acquisition of pronunciation within a communicative approach. Hispania 80(1), 95108.

[7] Henderson, A., Frost, D., Tergujeff, E., Kautzsch, A., Murphy, D., Kirkova-Naskova, A., Waniek-Klimczak, E., Levey, D., Cunningham, U. \& Curnick, L. (forthcoming). The English Pronunciation Teaching in Europe Survey: Selected results of a pilot study.

[8] Hirvonen, P. (1967). On the Problems Met by Finnish Students in Learning the Rising Interrogative Intonation of English. Publications of the Phonetics Department of the University of Turku. Turku, Finland: University of Turku.

[9] Hirvonen, P. (1970). Finnish and English Communicative Intonation. Publications of the Phonetics Department of the University of Turku. Turku, Finland: University of Turku.

[10] Hopkins, D. (2008). Teacher's Guide to Classroom Research. Berkshire, UK: McGraw Hill, Open University Press.

[11] Jenkins, J. (2000). The phonology of English as an international language: new models, new norms, new goals. Oxford, UK: Oxford University Press.

[12] Katayama, A. (2007). Japanese EFL Students' Preferences towards Correction of Classroom Oral Errors. Asian EFL Journal, 9(4), 289-305. 
[13] Kumpulainen, T. (ed.) (2010). Koulutuksen määrälliset indikaattorit 2010. Helsinki, Finland: Finnish National Board of Education. Available http://www.oph.fi/download/130716_Koulutuksen_maaralliset_indikaattorit_2010.pdf

[14] Lane, L. (2010). Tips for Teaching Pronunciation: A Practical Approach. New York, NY: Pearson Longman.

[15] Lehtonen, J., Sajavaara, K. \& May, A. (1977). Spoken English: the perception and production of English on a Finnish-English contrastive basis. Jyväskylä, Finland: Gummerus.

[16] Leppänen, S., Pitkänen-Huhta, A., Nikula, T., Kytölä, S., Törmäkangas, T., Nissinen, K., Kääntä, L., Räisänen, T., Laitinen, M., Pahta, P., Koskela, H., Lähdesmäki, S. \& Jousmäki, H. (2011). National Survey on the English Language in Finland: Uses, meanings and attitudes. Studies in Variation, Contacts and Change in English, Vol. 5. Retrieved http://www.helsinki.fi/varieng/journal/volumes/05/.

[17] Lintunen, P. (2004). Pronunciation and Phonemic Transcription: A study of advanced Finnish learners of English. Turku, Finland: University of Turku.

[18] Mauranen, A. \& Ranta, E. (eds.) (2009). English as a Lingua Franca: Studies and Findings. Newcastle upon Tyne: Cambridge Scholars Publishing.

[19] Macdonald, D., Yule, G. \& Powers, M. (1994). Attempts to improve L2 pronunciation: The variable effects of different types of instruction. Language Learning 44(1), 75-100.

[20] Morris-Wilson, I. (1992). English Segmental Phonetics for Finns. Helsinki, Finland: Finn Lectura.

[21] Neufeld, G. \& Schneiderman, E. (1980). Prosodic and Articulatory Features in Adult Language Learning. In Scarcella, R.C. \& Krashen, S.D. (eds.), Research in Second Language Acquisition. Rowley, MA: Newbury House. 105-109.

[22] Nicholas, H., Lightbow, P. \& Spada, N. (2001). Recast as feedback to language learners. Language Learning, 5(4), 719-758.

[23] Niemi, J. (1984). Word level stress and prominence in Finnish and English: acoustic experiments on production and perception. Joensuu, Finland: University of Joensuu.

[24] Pennington, M.C. \& Richards, J.C. (1986). Pronunciation Revisited. TESOL Quarterly 20(2), 207-225.

[25] Rogerson-Revell, P. (2011). English Phonology and Pronunciation Teaching. London, UK: Continuum.

[26] Seidlhofer, B. (2011). Understanding English as a Lingua Franca. Oxford: Oxford University Press.

[27] Seidlhofer, B. (2001). Pronunciation. In Carter, R. and Nunan, D. (eds.), The Cambridge guide to teaching English to speakers of other languages. Cambridge, UK: Cambridge University Press.

[28] Suomi, K. (1980). Voicing in English and Finnish stops. Publications of the Department of Finnish and General Linguistics of the University of Turku. Turku, Finland: University of Turku.

[29] Suomi, K., Toivanen, J. \& Ylitalo, R. (2008). Finnish sound structure. Phonetics, phonology, phonotactics and prosody. Oulu, Finland: University of Oulu.

[30] Tergujeff, E. (2010). Pronunciation teaching materials in Finnish EFL textbooks. In Henderson, A. (ed.), English Pronunciation: Issues and Practices (EPIP): Proceedings of the First International Conference. June 3-5 2009, Universite de Savoie, Chambéry, France. Université de Savoie, France: Laboratoire LLS. 189-205.

[31] Tergujeff, E., Ullakonoja, R. \& Dufva, H. (2011). Phonetics and Foreign Language Teaching in Finland. In Werner, S. \& Kinnunen, T. (eds.), XXVI Fonetiikan päivät 2010. Joensuu, Finland: University of Eastern Finland. 63-68.

[32] Toivanen, J.H. (2001). Perspectives on intonation: English, Finnish and English spoken by Finns. Frankfurt am Main, Germany: Peter Lang.

[33] Wells, J.C. (2008). Longman Pronunciation Dictionary. Third edition. Harlow, UK: Pearson Education Limited.

[34] Wiik, K. (1965). Finnish and English Vowels. Annales Universitatis Turkuensis B 94. Turku, Finland: University of Turku.

[35] Wiik, K. (1966). Finnish and English Laterals. Publications of the Phonetics Department of the University of Turku. Turku, Finland: University of Turku.

[36] Wragg, E.C. (1999). Introduction to Classroom Observation. 2nd edition. London, UK: Routledge.

Elina Tergujeff, M.A., is a Ph.D. candidate in Applied Linguistics at the University of Jyväskylä, Finland. She is also a qualified EFL teacher and teacher of Swedish as a second language. Her ongoing doctoral study focusses on English pronunciation teaching in the context of Finnish schools. 